\title{
AS IMAGENS DO SENHOR BOM JESUS, VENE- RADAS EM MATOSINHOS (PORTUGAL) E EM CONGONHAS DO CAMPO (BRASIL) $\left(^{\star}\right)$.
}

Matosinhos, povoação marítima milenar do Norte de Portugal, a qual se chamou também, através dos séculos, Matesinus, Matusiny e finalmente Matosinhos, tem seu nome ligado à seguinte lenda: por volta do primeiro século da éra cristã, quando Roma ainda estendia seu domínio a tôda a Península Ibérica, um dos seus prepostos, Caio Carpo, governador da Maia, celebrava seus desposórios com a patrícia Cláudia Lupa, nas alturas do ano 44 ou 46 . Para festejar tais bodas, organizara, numa praia próxima à foz do atual Rio Douro, jogos e cavalhadas em que êle próprio tomava parte. Súbito, premida pela calmaria, estacou nas imediações estranha embarcação, em cujo bôjo se transportava para Campostela o corpo inanimado de São Tiago Apóstolo, martirizado em Jerusalém. Investindo pelo mar a dentro, conduziu a montaria o cavaleiro régio, sem nenhum dano para êle, até a nau. $\mathrm{E}$, então, operouse naquele local o prodígio da conversão do nobre romano à doutrina de Cristo, recebendo no ato as águas lustrais do batismo. De volta à terra, incólume, cavalgando sua alimária, serviu Caio Carpo de espanto a quantos presenciaram a cena, os quais, por sua vez, acabaram por acompanhá-lo, abraçando o Cristinismo e propagando-o por tôda a Lusitânia. Tão curiosa lenda foi posta em letra de fôrma, com visos de autenticidade, por autores católicos dos séculos XVII e XVIII (1).

A essa praia, segundo outra lendária tradição, no sítio chamado Espinheiro, foi ter, durante o II século de nossa éra

\footnotetext{
(*). - Trabalho apresentado ao IV Colóquio de Bistudos Luso-Brasileiros, reunido na Cidade do Salvador (Bahia)l, em agôsto de 1959.

(1). - Antônio Coelho do Freitas - "Tratado da Veneranda e Prodigiosa Imagem do Senhor de Bouças de Matosinhos...", Cap. 2 - "Do nome de Matosinhos e sua etimologia", págs. 3-6. Coimbra, 1699.

António Cerqueira Pinto - "Filstória da prodigiosa imagem de Cristo Crucificado, que com o título de Bom Jesus de Bouças se venera no ligar de Matosinhos na Lusitania...", Assunto II, Cap. LVI - "Da Ethymologin do nome de Matosinhos"' págs. 202-203, Lisboa Ocidental, 1737.
} 
(2), artística imagem de Cristo Crucificado, coberta de espêssa vegetação marinha, à qual faltava o braço esquerdo. Recolhida por fiéis a uma capelinha próxima, não tardou que surgisse o membro ausente, encontrado de mistura com madeiros diversos atirados à praia pelo mar (3). Semelhante representação do Senhor désde logo passou a ser venerada como taumaturga por quantos a cercaram, estendendo-se a fama de seus milagres' em raio 'sempre crescente. Para explicar sua estranha procedência ganhou corpo mais outra interessante lenda: fôra seu artífice Nicodemos, o fariseu converso, testemunha do drama do Calvário e que, juntamente com José de Arimatéia, despregou o corpo de Cristo da cruz, recolhendo-o ao sepulcró. Nicoldemos, antigo membro do Sinédrio judaico, depois de abjurar a lei mosaicá, sofreu atroz perseguięão 'de seus anteriores comparsas, indo recolher-se foragido à herdade de seu tio Gamaliel. Na quietude dêste retiro, sem outras preocupações, dedicou-se a' esculpir imagens do Senhor nas vascas dà àonia; fábricando pelo menos quatro. Uma destas; talvez a primeira, fôra lançada ao mar, no pôrto de Jopé (Jafa), na Palestina, pelo próprio autor, a fim de poupá-la à profanação por parte dos persèguidores dos "cristãos, durante um dos vários massacres ordenados pelos imperadores romanos. Ao sahor das vagas e das correntes marinhas, sulcara todo o Medi-

(2). - A. Cerqueira Pinto: chega a mencionar, em sua obra já citada. o dia exato em que semelhante fato sucedeu: terça-feira, 3 de maio do ano 162 da éra de César, correspondente ao 124 da éra đe Cristo. Estribou-se para isso afiançar em depoimentos de: antigos autores e, sobretudo, na inskriçäa numérica gravada no secular padrão fincado no ponto da suposta invenção da imagem.

(3). - A propósito do tardio aparecimento do braço esquerdof, Pinho Leàl dá curso a mais outra pitoresca história, desta forma enunciada: "Duranite 50 anos foi o. Senhor venerado sem o braço, com que apareceu de menos, pois que muitos braços se fizeram, mas nenhum dêles se ajustava ou prendia ao tronco, tornando-se logo manifesto um novo milagre daquela sacrossanta imagem. - Andava, porém, um dia na praia uma pobre mulherzinha de Matosinhos, 'apanhendo nos desperdícios do mar, com que alimentasse o lume, e acontecieu evicontrar um objeto que the pareceu bom para queimar. Chegando à casa deitou-o ao fogo, mas aquilo que lhe parecia um bocado de lenha, : saltou fora da fogueira tantas vêzes quantas ela ali o deitou. /. Tinha esta mulherzinha uma fitha muda e olhando esta para o que a mãe fazia, cờ grande assômbro de todos falou e disse: - 6 minha mãe, não teime em deitar isso ao fogo, olhe que $\&$ braço de Nosso Senhor de Bouças (porque então se venerava ainda a imagem e verierou até ao mềdo do século XVI 'no templo que" ém Bouças se the erigiu pouco depois do seu aparecimento). / Attonita"a pobre mulher pelos mìllagrés que presenciava, correu a dar parte dêlas à povóação, a qual foi verificar se aquêle era ou não o braço que faltava-aó Sentory e com assômbro viu que tão ajustado the ficavà que depois năo se conhecia já qual dêles tinha faltado!" ("Portugal Antigo e Moderno", dicionário geográfico, estatístico, corográfico, heráldico, arqueológico, histórico, biográfico 'e etimológico de tôdas 'as cidades, vilas' e freguesias de Portugal e 'de' grande número de aldeias, vol. V, pág. 140, Lisboa, 1875). 
terrâneo e chegara ao Atlântico, indo dar à costa na praia de Matosinhos.

Dada a inverossimilhança de tal lenda, por isso que o culto do Crucificado só teve início a partir do século VIII depois de Cristo, tratei de apurar a que época se deveria filiar a imagem em aprêço. O único elemento positivo que me foi fornecido a princípio, obtive-o da obra de Correia de Campos, intituląda." Imagens de. Cristo em Portugal", editada pela Livraria Bertrand (Lisboa, s. d. .). Admite êsse arqueólogo, após rever as diferentes formas de representação do Bom Jesus pela Cristandade, no curso de sucessivas idades, que sòmente no séculọ XI começaram a generalizar-se na Hispânia Oriental os crucifixos. Estudando, mais adiante, de maneira especial, os Cristos portuguêses, vem a distribuí-los em três ciclos a saber: a) Cristo ressuscitado; b) Cristo passional; c) Cristo realista. Ao segundo dêsses períodos, o qual principiou em Portugal por volta do século XIV, filia as imagens do Crucificado. Entretanto, referindo-se às três de feição artística mais antiga, conhecidas no país (4), situa apenas duas delas na quadra inicial dêsse ciclo, ou sejam: o Cristo Negro do Museu de Machado de Castro (5), em Coimbra, e o do Convento dos Bernardos, em Almoster. A terceira é justamente o Bom Jesus de Bouças (Matosinhos), cuja feitura o retro-citado autor, levando em conta "o frisado da barba, em canudos como dedos", pretende recuar até o século XII.(6). Assim sendo, é a mais velha representação de Cristo Sofredor existente em terras lusas.

Procurando averiguar até que ponto se podia aceitar como fundada essa dedução, dirigi-me a diversos eminentes professôres de Portugal. O único a responder às minhas indagações, nessa ocasião (agôsto de 1957), foi o Dr. João Albino Pinto Ferreira, diretor do Gabinete de História da Cidade do Pôrto. Con-

(4). - Na obra "Cristo na Arte", editada em 1955 pelo Gabinete de História da Cidade do Pôrto, vol. XXVII dos "Daçumentos e Memórias para a História do Pôrto", figura, todavia, como do século XIII, certa imagem de Cristo Crucificado, pertencente à :Câmara Municipal do Pôrto depositada no Museu Nacional de Soares dos Reis da mesma cidade (Estampa 3).

(5). - Ao compor a conferência intitulada "O Cristo dos que choram" intercalada no retro-referido livro "Cristo na Arte", reportou-se o Pe. Miguel de Oliveira a essa imagem e, após mencionar ter estado ela no Oratório das Donas e depois em Santa Cruz antes de ser recolhida no Museu de Coimbra, assim a descreve: "Todo pintado de. negro, apenas com o cendal branco (por isso the chamamı o Cristo Negro), é uma imagem de dor que chega a atingir expressão dramática: tronco alongado.e pendente da cruz pelos braços; cabeça coroada de espinhos e inclinada para a frente; braços descarnados e gptejantes de sangue; pernas flectidas pelo pêso do corpo; olhos e lábios semi-cerrados numa sombra de agonia..." (op. cit., pág. 46).

(6) . - Correia de Campos - "Imagenjs de Cristo em Portugal", págs. 145-146, 'Lisboa, s. d. 
fessou-me, lealmente, que nenhum elemento tinha para esclarecer-me no particular, mas ia fazer investigações a respeito e, oportunamente, me daria ciência. De fato, estudando, sob todos os ângulos, a referida imagem, que fêz despir dos ornatos artificiais (cabeleira postiça, etc.), chegou êsse pesquisador às mesmas conclusões de Correia de Campos, apresentando importante comunicação ao Colóquio de Estudos Etnográficos comemorativo do centenário de nascimento de Leite de Vasconcelos, realizado no Pôrto, em junho de 1958. Tal trabalho, que se intitulou "A Escultura do Bom Jesus de Bouças" (Nótula Histórica e Etnográfica) (7), traz em apenso magnífica série de estampas, representando a imagem do Senhor de Matosinhos de corpo inteiro, em várias posições, e diversos pormenores da cabeça. Gentilmente, cedeu-me o Dr. Pinto Ferreira os negativos de algumas dessas fotografias, permitindo-me assim 'fazer cópias adeqüadas que junto ao presente estudo (fotos I e II). Confrontando êsses elementos com os por mim obtidos em Congonhas do Campo, pude estabelecer comparações interessantes que explanarei mais adiante.

No decorrer do século XVIII, propagou-se intensamente no Brasil, a devoção ao Senhor de Matosinhos, transportada para cá pelos habitantes peninsulares. As minas de ouro, então descobertas nas Gerais, atraindo emigrantes ávidos de riqueza fácil, procedentes sobretudo do Norte de Portugal, tornaram-se sede de múltiplas instituições de culto ao Bom Jesus, com aquela designação específica (8). Dentre elas sobressaiu a implan-

(7). - Estampada no "Boletim Cultural" da Câmara Municipal do Pôrto, vol, XXI, fasc. 1-2.

(8). - 0 insigne historiador mineiro, Cônego Raimundo Tríndede, em sua substanciosa obra "Instituições de Igrejas no Bispado de Mariana" (publicação n.o 13 do Serviço do Patrimônio Histórico e Artístico Nacional, M. E. S., Rio de Janeiro, 1945), enumera debaixo da epígrafe Matosinhas, sete igrejas que têm como orago o antiquíssimo Senhor de Bouças. Aléml disso, resta outrossima, assinalar, no livro referido, o verbete Passa Dez, relativo à capella situada no Alto das Cabeças, em Ouro Prêto, qual tem' por titulares, conforme Furtado do Menezes, os Santíssimos Corações de Jesus, Maria e /José, São Miguel e Almas, e o Bom Jesus de Matosinhos, e se instalou por provisão de 12 de agôsto de 1771, a peđido de Manurel de Jesus Toste. / Por ordem cronolígica das licenças eclesiásticas, que permitiram ou sancionaram als resplectivas fundações, assim se distribuem os templos atrás mencionados, segundo os respectivos dados fornecidos pelo Cônego Trindade.

1.0). - Santuário em Congonhas do Campo, erecto no Alto do Maranhão, por solicitação de Feliciano Mendes, mercê da prọvisão episcopal de 21 de junho de 1757. 1768.

2.0). Capela em Lavras do Funil, por provisão de 23 de agôsto de 
tada por Feliciano Mendes, no Alto do Maranhão, no local chamado Arraial das Congonhas do Campo. Produto de um exvoto dêsse colono luso, vítima de pertinaz moléstia, que guareceu mercê da intervenção divina por êle invocada, surgiu, a princípio, modesta capela, logo transformada num dos mais ricos e suntuosos templos da região, graças à colaboração de eminentes artistas mineiros, entre outros, o célebre Aleijadinho.

Nesse santuário, hoje elevado à categoria de Basílica Menor pelo Breve "Pietatis artisque monumentum", expedido por Pio XII, em 26 de julho de 1957, e um dos mais expressivos da atualidade no Brasil, se encontram duas imagens do Senhor Bom Jesus, expostas à veneração dos fiéis no altar-mor: um grande Crucificado, a ocupar o trono, e um Senhor Morto jacente, depositado na parte dianteira e inferior.

Sabe-se, com segurança, que êste último foi ali colocado em janeiro de 1787 (9), tornando-se o fulcro de ardente devoção, mantida até o presente. Quanto à outra imagem, existente no trono, reza a tradição popular, corrente ainda hoje em Congonhas do Campo, que substituiu a primitiva, então despregada da cruz e recolhida ao sepulcro do altar-mor. Nenhum dado positivo, porém, ficou arquivado nos papéis da irmandade a êsse respeito.

Em fevereiro dêste ano (1959), indo a Congonhas pela terceira vez, expressamente para fotografar as duas imagens do Senhor, acima aludidas, dei rigorosa busca no arquivo, junta-

3.0). - Santuário em Conceiçāo do Mato Dentro, erecto no antigo povoado do mesmo nome, situado no Distrito Diamantino de Sêrro Frio, mediante provisăo de 21 de abril de 1770 .

4.0). - Capela em São Miguel do Piracicaba, no "arraial do Morro". a pedido de Lứs Pereira da Silva. Provisão de bênção de 8 de junho de 1771. A bênção da imagem do Bom Jesus se realizou a 29 de junho do mesmo ano.

5.0). - Capela na Vila to Príncipe (atual cidade do Sêrro), "na paragem chamada Lagoa de Matosinhos" tendo sido seu fundador o Tenente Jasé Ferreira de Vila Nova Ivo, que justificou judicialmente, em 1781! essa instituição.

6.0). - Capela em São João del Rei, "na Vargem do Pôtto". Patrimônio doado pelo Pe. Dr. Matias Antônio Salgado em 14 de maio de 1773 . Construção autorizada por provisäo de 6 de setembro de 1771 .

7.0). - Capela filial de Roça Granda, fundada por Inácio Pires de Miranda mediante provisão de 30 de maio de 1774 . Tornada freguéria colativa por alvará imperial de 10 de maio de 1823 , desmembrando-a da paŕ́quia de Santa Luzia, foi instituída canônicamente em 8 de outubro do mesmo ano. Pertence hoje à novissima Diocese de Sete Lagoas, e acabou por dar nome à povoação que se formou e cresceu em seu derredor, cidade de Matosinhos agora chamada.

(9). - Apud Jútio Engrácia - "Relação Cronológica do Santuário e Irmandade do Senhor Bom Jesus de Congonhas do Campo" $\longrightarrow$ in $\longrightarrow$ "Revista do Arquivo Páblico Mineiro", ano VIII, fascículos I e II, janeiro a junho de 1903, pág. 50, Belo Horizonte, 1903. 
mente com o Pe: João Fagundes, C. Ss...R., seu reorganizador. Encontramos, então, alguns indicios que nos permitiram 'trazer alguma luz em tal sentido. Assim é que achamos um conjunto de fôlhas destacadas dum livro da época, numeradas de 108 a 112 e rubricadas com a assinatura de Correia de tal, nas quais se contém o "Treslado do inventário dos bens pertencentes sòmente à Capela do Senhor Bom Jesus de Matosinhos, -que se fêz por falecimento do Ermitão Feliciano Mendes"..No anverso da fôlha 108, lê-se:

"Uma imagem do Senhor Bom Jesus, de vulto, que se acha colocada no altar-mor com seu resplendor de papelão: Item: Outra imagem do mesmo Senhor de vulto, que mandou vir e deixou em seu testamentó Joseph Roiz Medina, e entregou seu testamenteiro o Cápitão Simão Ribeiro de Sousa, que se acha por colocar".

No verso dessa mesma fôlha 108 , lê-se, como $1 .^{\circ}$ item:

"Item: Quatro toalhas de cingir o Senhor Bom. Jesus, das quais uma é de cambrey fina com seus recortados e bordada, outra de esguião bordada e com recórtados, outras duas de bertanha com renda".

Diante de tais dados fácil nos foi fazer a seguinte conjectura: se existiam quatro toalhas para cingir o Senhor, elas só podiam destinar-se à imagem que se achava então no trono do altar-mor, pouco provida de vestes naturais, a qual é exatamente a hoje depositada no sepulcro. A outra, que estava por colocar, deve ser a atualmente existente no trono, a qual dispensa êsses complementos de indumentária, como se pode apreciar na foto III. Em face dêsse raciocínio, o Senhor Morto jacente foi, pois, a primitiva imagem colocada no trono do altarmor, substituída no último quartel setecentista pela que se acha presentemente em tal lugar de honra. Nossa dedução condiz, pois, com a tradição, podendo-se explicar os fatos sucedidos da maneira que se segue: logo após a morte de Feliciano Mendes, ocorrida em 23-9-1765, havia duas imagens do Senhor Bom Jesus: uma disposta no altar-mor, provàvelmente mandada vir de Portugal pelo primeiro ermitão, "e outra chegada depois, oferta do devoto Joseph Roiz Medina. Esta última, ainda por se colocar naquela ocasião, veio a ser instalada no trono, descendo-se a primitiva, após o desprendimento da cruz, para o sepulcro. A devoção popular inicial, concebida em tôrno da mais antiga, conservou-se fiel, transmitida de geração em geração, até o presente. 


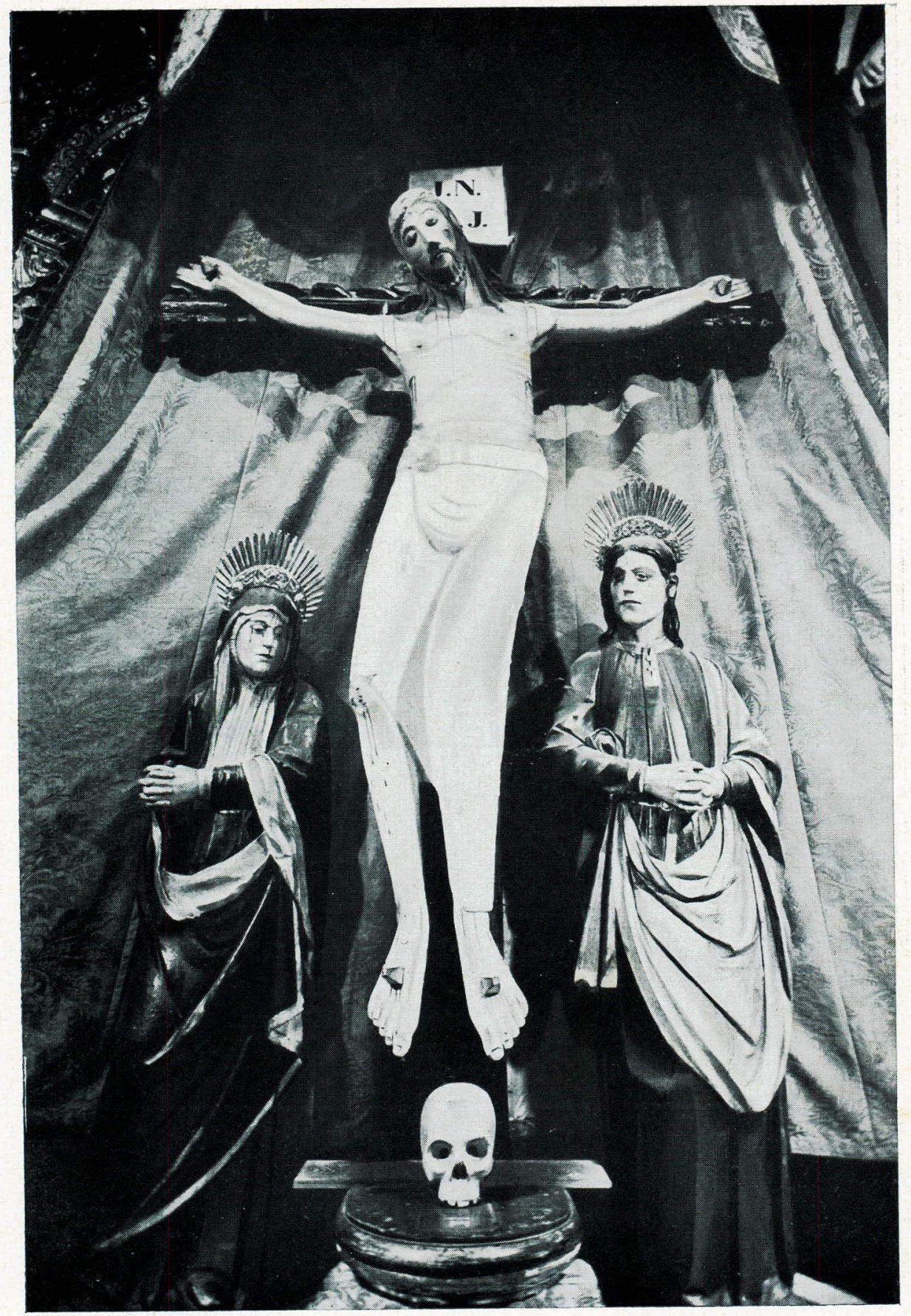

I. - Imag am do Senhor Bom Jesus, venerada em Matosinhos (Portuga1). Foto cedida pelo Gabinete de História da Cidade do Pôrto. 


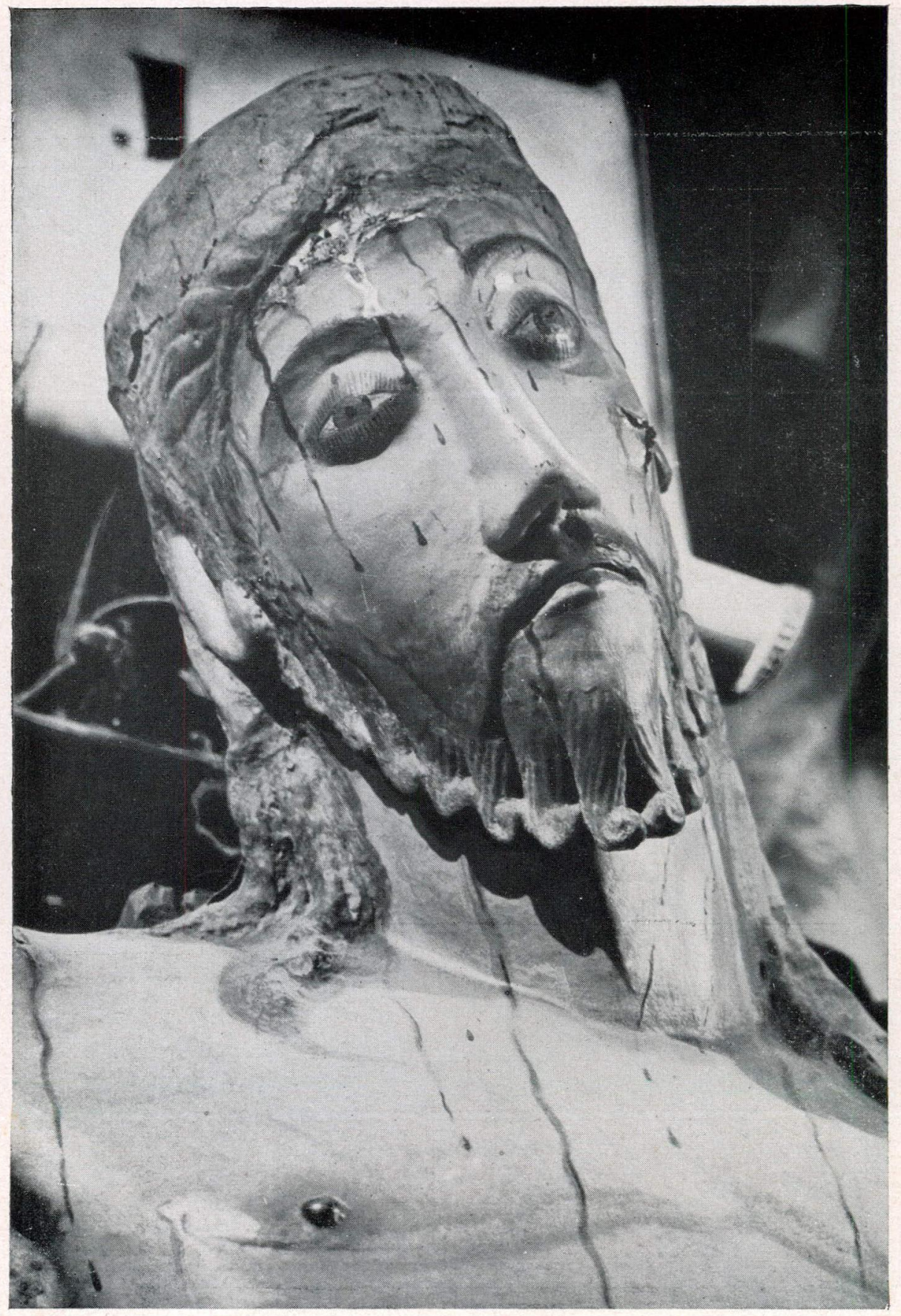

II. - Pormenor da imagem do Senhor Bom Jesus, vencrada em Matosinhos (Portugal). Foto cedida pelo Gabinete de História da C dade do Pôrto. 


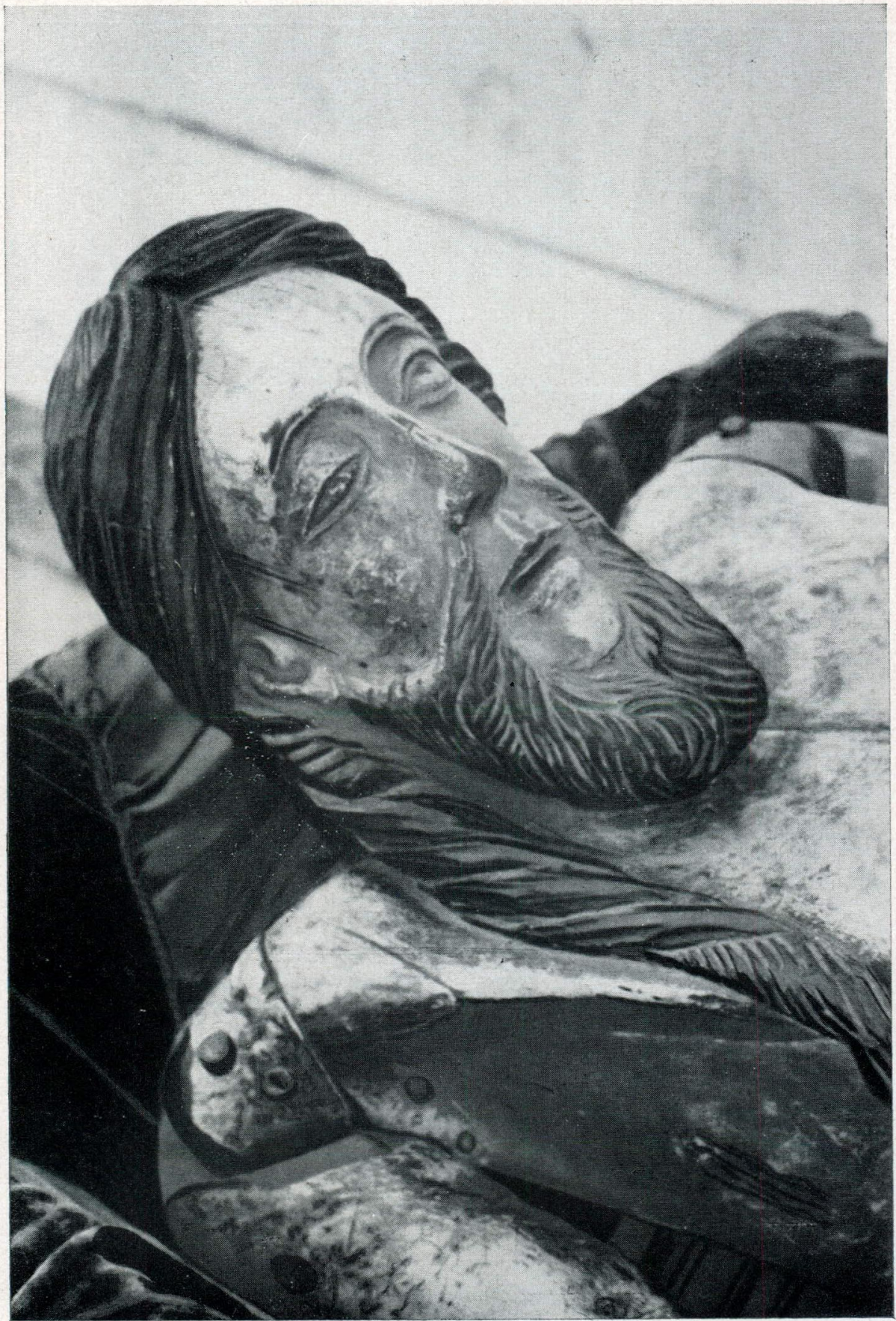

IV. - Pormenor (perfil direito) da imagem jacente do Senhor Bom Jesus, venerada na Basílica de Congonhas do Campo (Brasil). Foto do Autor. 


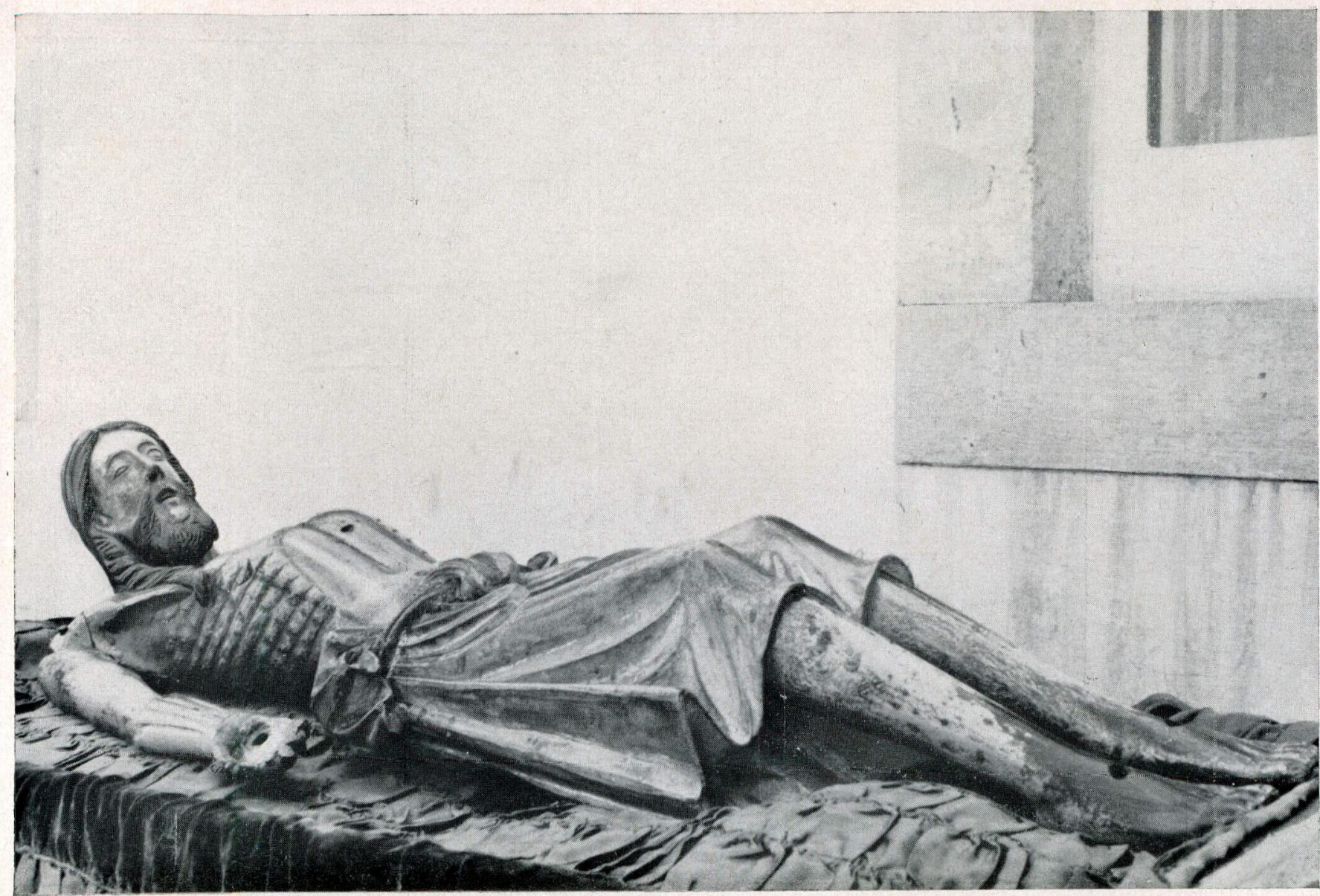

III. - Imagem jaçnte do Senhor Bom Jesus, venerada na Basilica de Congonhas do Campo (Brasil). Foto do Autor. 


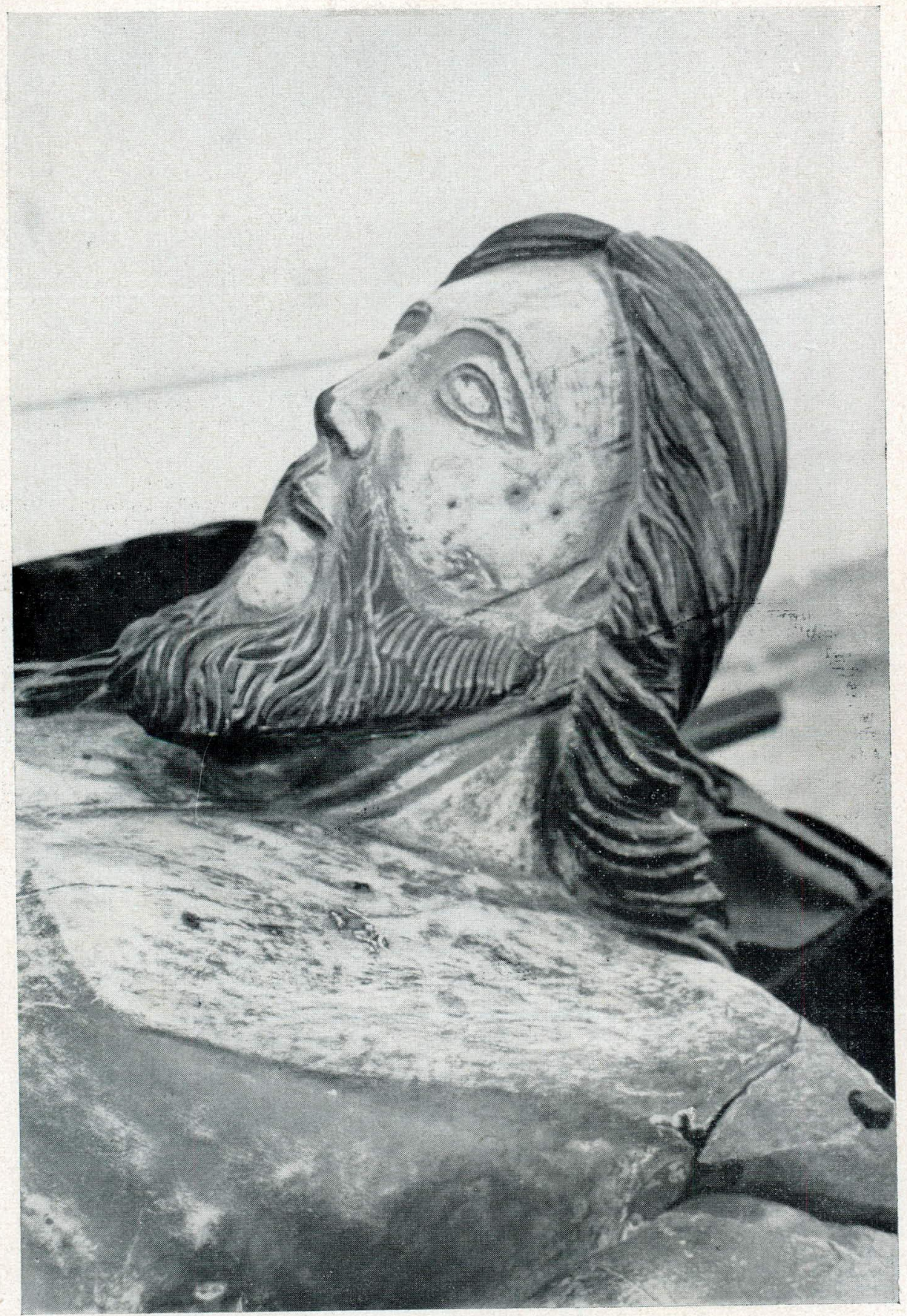

V. - Pormenor (perfil esquerdo) da imagem jacente do Senhor Bom Jesus; venerada na Basílica de Congonhas do Campo (Brasil). Foto do Autor. 


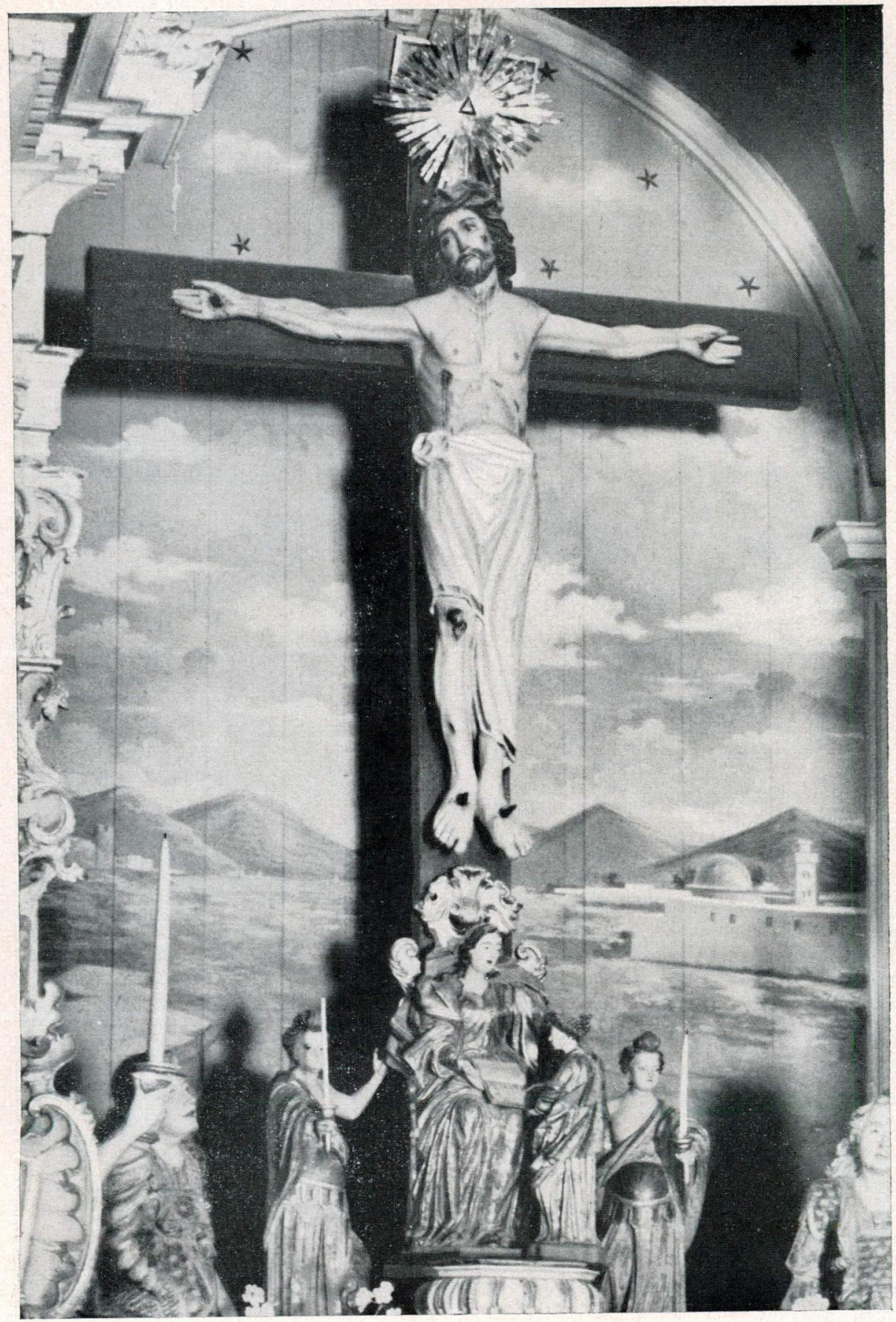

VI. - Imagem da Senhor Bom Jesus (Crucificado) colocada no trono do altar-mor, venerada na Basílica de Congonhas do Campo (Brasil). Foto do Autor. 
Pela análise das fotografias, por mim obtidas (III, IV, $\mathrm{V}$ e VI), observa-se que a atualmente colocada no trono muito se assemelha ao Bom Jesus do Monte, de Braga, ostentando um Cristo vivo, vigoroso, embora pregado à cruz. O Senhor do Sepulcro, contudo, traduz o estado dum agonizante, após intenso sofrimento, com as pálpebras semi-cerradas, apresentando os olhos certo grau de estrabismo no sentido vertical. Esta é a única semelhança que mostra em relação ao simulacro de Matosinhos. Dêste difere essencialmente no aspecto da cabeleira e da barba. Ambas as imagens existentes em Congonhas são esculturas portuguêsas seculares, sendo a do trono evidentemente bem mais nova.

\section{EDGARD DE CERQUEIRA FALCÃO}

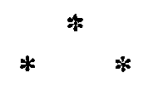

RESU MO.

O Autor estuda de inicio a origem lendária da imagem do Bom Jesus de Matosinhos, de Portugal. Em seguida, analisa a opinião que a filia ao século XII, manifestada por estudiosos portuguêses. L.ogo após, aprecia a devoção implantada no Brasil, particularmente em Congonhas do Campo, produto dum ex-voto de certo emigrar:te português. Finalmente, tecendo considerações sôbre as duas imagrons do Senhor Bom Jesus existentes nesse santuário mineiro, ch gá à conclusão de ser a que jaz atualmente no sepúlcro do altarn!or, a que esteve colocada, a principio, no trono dêste último. Seis fotografias ilustram o trabalho, mostrando as aludidas imagens eni stu todo e com pormenores. 